IRSH SI (2006), pp. 4I 5-439 DOI: I0.I0I7/So020859006002549

(C) 2006 Internationaal Instituut voor Sociale Geschiedenis

\title{
Labour Formation, Identity, and Resistance in HM Dockyard, Singapore (192I-I97I)
}

\author{
LIEW KAI KHIUN
}

Summary: For close on half a century, the British naval dockyard in Singapore was a prominent employer in the colony. The huge facility attracted migrant workers from the region, and entire settlements and communities were established around the premises of the dockyard as well. This article seeks to place the legacy of Singapore's naval-base workers within the historical contexts of the entanglements between imperialism, diaspora, social movements, and labour resistance. The development of international labour flows, formation, and identity was reflected in the prominence of the migrant Malayalee community and its socio-religious organizations at the naval base. Furthermore, the routine individual defiance and industrial unrest went beyond disputes about wage levels and working conditions. They were enmeshed within the broader undercurrents of Singapore's transitory political culture, and between the interwar decades and the period of decolonization disturbances at the naval dockyard became part of larger political contestations.

Looking back, there is a tragedy in the thought of the armies of craftsmen and labourers in Scotland and the northern estuaries of England, who built this multitude of ships to roam the world but spent every night of their lives in dreadful tenements, or the clerks on the stools of the magnates' office, writing out lists of cargo for exotic ports they could never hope to see. But poets of Empire could find romance in it all. ${ }^{\mathrm{I}}$

How dare you. I demand apology. Who you think you are? Just because you young, educated, you think you can be arrogant to me? Let me tell you who I am. I A.P. Velloo. Before you born, I already educated, working. Working with the British Armed Forces. They show me respect, they give respect to A.P. Velloo! ${ }^{2}$

\section{INTRODUCTION: “THEY SHOWED ME RESPECT”}

A.P. Velloo is a caricature in novelist Catherine Lim's story of one of the countless ethnic Indian workers forced into retirement by the withdrawal of the British military from Singapore in I97I. Considering himself a

I. David Howarth, Sovereign of the Seas: The Story of British Sea Power (London, 1974), p. 333. Howarth provides a useful description of the working conditions of British civilian dock workers in the nineteenth century.

2. Catherine Lim, Or Else, The Lightning God and Other Short Stories (Singapore, 1980), p. 30. 
proud British subject, Velloo personified the entire generation of workers who struggled to retain their pride in a rapidly modernizing postcolonial city-state. ${ }^{3}$ They were part of the legacy of the significantly heightened investment in defence in British Malaya and Singapore beginning in the interwar decades. At its peak, there were about 40,000 Asian employees and their families on the direct payroll of the various armed services in Singapore alone.

It was in the naval dockyard in the northern tip of Singapore that the largest concentration of labour was located, with an estimated of 10,000 employees, many of whom were ethnic Malayalees from southern India. The very prevalence of the Malayalam-based theatre form of Kathakali around the naval base was a testimony to the presence and influence of a transnational labour force within one of the most prominent icons of British imperialism. ${ }^{4}$ Using mostly previously unexamined and declassified official records and oral interviews with former employees from the base, this article seeks to uncover the historical development of a workingclass community within that base. ${ }^{5}$

Their narratives are used here to review critically the directions, not just of the social histories of naval dockyards, but also of broader sociocultural themes. They will highlight the emergence of social identities different from those envisaged by the naval authorities. Through its socioreligious institutions, the Malayalee community from southern India was one of the more distinct groups, with a strong visible presence in the naval dockyard. As will be elaborated later, its legacy was not only linked to that of the base, it also reflected underlying transnational and migratory patterns that have not been adequately recognized in the imperial and national historiographies. The articulation of labour consciousness through trade unions and industrial action will also command significant attention in this respect. In spite of their ambiguous legal status, these workers showed considerable resistance, not only to their British employers, but also to the ruthless Japanese naval authorities and the authoritarian government of the postcolonial People's Action Party (PAP). By studying the legacy of the naval-base workers, we hope to highlight the complexities in the interactions between empire, diaspora,

\section{Ibid.,pp.22-38.}

4. Literally translated as "story-play", Kathakali is a seventeenth-century theatre genre that has its origins in Kerala. Considered a popular "people's theatre", Kathakali incorporated the Hindu epic tales of Ramayana and Mahabharata, which are played out by masked performers representing gods, demons, and humans. See David Bolland, $A$ Guide to Kathakali: With the Stories of 35 Plays (New Delhi, 1996).

5. The historiography of the socio-economic legacy of the Singapore dockyard is far from comprehensive. Admiralty records pertaining to the base's industrial relations are scattered and consist mostly of more general reports and correspondence. Furthermore, the records of the Singapore government and of the successors to the various armed services unions, crucial in furnishing a more comprehensive account, remain inaccessible. 
and labour, where workers, navies, governments, cultures, and politics converged.

\section{THREE CHRONOLOGIES: A BRIEF BACKGROUND TO THE NAVAL DOCKYARD}

The narrative of the naval base in Singapore can perhaps be elaborated along three parallel lines: strategic, institutional, and social. The first concerns the context of the base within British naval strategies; the second pertains to the institution of the Royal Navy with regard to industrial relations; the third takes place within a more localized setting of the role of the base in shaping socio-cultural formations. Until the end World War I and the centenary of Britain's military presence in Singapore in 1919, its military presence in Malaya was modest at best. ${ }^{6}$ But the Japanese threat during the interwar decades compelled London to strengthen its naval commitment in southeast Asia. Already a major trading emporium by the I920s, the colony of Singapore was selected to be the site of a grand naval dockyard to demonstrate British imperial resolve. Although the construction of the base commenced in the early 1920s, it was not opened until 1938, having been delayed by disarmament and naval-limitation treaty obligations, as well as by engineering difficulties in converting an isolated swampland into a functioning battle station. ${ }^{7}$

Within a few years of its completion, the naval dockyard was one of the first targets of Japanese bombers as the storm clouds of World War II arrived in southeast Asia. By the end of January 1942, the British were forced to put the naval base to the torch as the rapidly advancing Imperial Japanese Army prepared for its final thrust into what Winston Churchill had proudly described as the impregnable fortress of Singapore. ${ }^{8}$ In their three-and-a-half-year occupation of Singapore, the Japanese naval authorities attempted, without much success, to restore the heavily damaged naval dockyard. ${ }^{9}$ With the advent of the Cold War, a dismantled British Empire was eclipsed by Soviet-American rivalry. In this respect, the naval base became more important to the local economy than in serving an Anglo grand strategy. In the mid-rg6os the base was slated for commercialization as the British began to accelerate the withdrawal of

6. See Malacom H. Murfett, John N. Miksic, Brian P. Farrell, and Chiang Ming Shun, Between Two Oceans: A Military History of Singapore from First Settlement to Final British Withdrawal (Singapore, 1999).

7. See James Neidpath, The Singapore Naval Base and the Defence of Britain's Eastern Empire, 1919-194I (Oxford, I98I).

8. See W. David McIntyre, The Rise and Fall of the Singapore Naval Base, 1919-1942 (London, I979).

9. Darren Seow Tien Ghin, "A Naval History of Singapore: the Syonan-to Episode, 1942-1945” (Honours thesis, National University of Singapore, 200I). 
their naval and military personnel from Singapore, a move that was completed formally by i $97 \mathrm{I}$.

The labour policies of the Admiralty, which provided the foundations of the social history of the base, can be divided into five main periods. The first, from the i 920 s until the near completion of the dockyard, involved the employment of a steady pool of low-waged and relatively unskilled casual workers to open up the land and undertake basic building work. By the mid-I930s attention had turned to the search for higher-skilled workers on a more permanent basis for maintaining the infrastructure. With war approaching, some of these workers, valued for their expertise, were flown to Ceylon, away from the Japanese. The return of the British marked the third stage of the Royal Navy's labour policy in the late I940s, encompassing massive employment schemes, both to reconstruct the base and to reduce postwar unemployment in Singapore. ${ }^{10}$ The fourth stage, from the i950s to the early I960s, saw the Admiralty endeavour to institutionalize a more stable industrial-relations climate in a turbulent political climate, where labour issues became enmeshed with anti-colonial nationalism. Problems relating to retrenchment and compensation for civilian staff made redundant by the armed services marked the final stage in an economy and defence policy heavily reliant upon the British military.

With the expansion of this imperial military infrastructure came the shifts both in demographic trends and, eventually, the island's political fault lines. The naval base and its surrounding aerodromes and army barracks were instrumental not only in the renewed influx of migrant labour, previously reduced by the Great Depression, but also in the outward movement of the colony's population, which had been largely confined to the densely settled municipal limits of the city. Even though a degree of permanence was evident in the settlements set up alongside these installations, those serving these installations - either directly or indirectly - were subjected to constant disruption. Few traces of the pioneering masses of Tamil coolies remained by the I930s, for instance, while war further dispersed the community that was beginning to emerge. There was some semblance of stability from the late I940s to the mid-I960s, but the social fabric of the population was once again affected by the closure of the military bases as well as by the drastic resettlement policies of the postcolonial PAP government. While the transient workers returned to the lands of their origins, by then nation-states, those remaining were channelled towards designated government public-housing estates.

Though the Royal Navy was keen to be aloof from local affairs, its dockyard management found itself dragged into political developments in Singapore. Across the island, localities were being turned into electoral 
districts and industrial disputes into political contests. With the armed services constituting one of the main employers on the island, the naval base became an important locus of political mobilization. The Malayan Communist Party (MCP) attempted to seize control of the newly formed unions between 1946 and 1948, while an industrial dispute in 1952 presented the first opportunity for political aspirants, such as Lee Kuan Yew, to platform their agendas. Similarly, a sixteen-day strike at the naval base in I955 was led by key political personalities such as Sydney Woodhull, demonstrating against not just the Admiralty but the local government as well. In I963 a bitter month-long industrial dispute at the dockyard became a battleground between the PAP government and its opponents. And, finally, the government had to contend with the spectre of high unemployment rates following the announcement of the withdrawal of the British military, an event considered the turning point in the political direction of Singapore. ${ }^{\mathrm{II}}$

\section{"FREAK SOCIAL AND CULTURAL DISPLACEMENTS"}

In spite of its historical significance, critical works on the social and labour legacies of the British military and naval presence in Singapore are nonexistent. Instead, attention has been overwhelmingly focused on the geopolitical and military aspects of the base. National narratives, on the other hand, have abstracted the naval base to one of a triumphant struggle on the part of the PAP government to build up the economy and defences of the tiny republic as Britain withdrew its security and financial umbrella. Hitherto, social and labour histories have made only passing mention of the working population and community around the vicinity of the military bases.

Waterfront labour has, however, been accorded scholarly interests in recent years. In addition to serving maritime commerce and naval power, the ports and dockyards were also home to distinctive waterfront communities that made these places into sites of contestation between labour and capital/military. ${ }^{\mathrm{I} 2}$ According to Hilson, the growing interest in the study of industrial relations in the European naval dockyards points "towards a considerably more complex model of dockyard labour. Far from being bought out by naval imperialism or repressed by military

I I. See Lee Kuan Yew, From Third World to First: The Singapore Story, 1965-2000 (Singapore, 2000).

I 2. For recent works see Sam Davis et al. (eds), Dock Workers: International Explorations in Comparative Labour History, 2 vols (London, 2000), and Kenneth Lunn and Ann Day (eds), History of Work and Labour Relations in the Royal Dockyards (London [etc.], 1999). 
discipline, dockyard workers made creative use of resources available to them to challenge aspects of their working conditions." I3

Historiographies of civil-labour relations in naval facilities have, however, been predominantly anglocentric. In situating the naval bases at Deptford, Woolwich, Chatham, Sheerness, Portsmouth, and Plymouth as the main dockyards of England, Roger Morris proceeded further to explain: "There were other smaller naval depots and small naval bases abroad at Gibraltar, Port Royal, Jamaica, Antigua and Halifax. [...]. Men in these small and foreign yards have little bargaining power and are vulnerable to victimisation and so did not usually join in large scale combinations." I4 Until Frederick Cooper's studies on port workers in colonial Mombasa, the narrative of waterfront labour had mostly been centred on the generally heroic discourses of European working-class dockers. ${ }^{15}$ Lamenting the hegemony of the proclaimed universalism of Western academia, in which "it has been too long that generalisations about Europe or America are taken as theory while studies from other parts of the world are considered descriptive or ethnographic", Thongchai Winichakul argued that the "'original' or 'authentic' narratives in western Europe should be considered as marginal, not central to world experience, and can be fully understood only when they encounter different experiences from around the world". ${ }^{16}$ In this respect, the case of the naval dockyard in Singapore seeks to decentralize and de-spatialize the narrative of dock workers from the waterfronts of the Euro-Atlantic wharves.

The resurrection of the legacy of Singapore's naval-base workers also represents a larger attempt to move beyond the straitjackets, not just of the traditional categories of naval and imperial histories, but also those of mainstream national histories. In the realm of national historiography, Wee highlights two interrelated dominant narratives, namely the "Whiggish telos" of modernization since the establishment of colonial rule in

I3. Mary Hilson, "Labour Politics in a Naval Dockyard: The Case of Karlskrona, Sweden c. I 880-1925”, International Review of Social History, 46 (2001), p. 342.

I4. Roger Morris, "Government and Community: The Changing Context of Labour Relations, I770-1830", in Lunn and Day, History of Work and Labour Relations, p. 2 I. Murfett has listed several categories of British military base worldwide according to their operational functions. They are as follows: the main support areas (Australia, Canada) - Sydney, Vancouver; operational naval bases - Aden, Bombay, Colombo, Freemantle, Karachi, Kilindini, Trincomalee, Auckland, Brisbane, Hong Kong, and Singapore; and advanced naval bases (Indian Ocean) - Addu Atoll, Andaman Islands, Bahrain, Mauritius, and Masirah Islands - (Pacific) Brunei, Port Darwin, and Manus; Malcolm H. Murfett, In Jeopardy: The Royal Navy and British Far Eastern Defence Policy, 1945-195 I (Oxford, 1995), p. 3.

I5. Frederick Cooper, On the African Waterfront: Urban Disorder and the Transformation of Work in Colonial Mombasa (New Haven, CT, 1987).

r6. Thongchai Winichakul, "Writing at the Interstices: Southeast Asian Historians and Postnational Histories in Southeast Asia”, in Abu Talib Ahmad and Liok Ee Tan (eds), New Terrains in Southeast Asian History (Singapore, 2003), p. 17. 
I 8 I9, and that of self-rule in Singapore in 1959, both of which foreground elite personalities. In this respect, Wee feels that the plotting of the PAP story as Singapore's history has not been seriously challenged either by professional historians or by former political actors, who were thus doubly defeated. ${ }^{17}$

Labour history generally, and the history of social movements in particular, has been demonized by national history into one of emotional workers swayed into riotous industrial action by shady political elements against the "moderate" policies of the PAP government. Instead, the latter rationalized the industrial-relations framework, rid labour of its militant influence, and ensured in turn workplace harmony under the direction of a state-supported labour movement. The treatment of social history in Singapore was also moulded by statist contemporary discourses on and classifications of social groups. Hence, attempts to write a more transnational history have been ghettoized by more essentialized notions of race and ethnicity over the more socially chequered landscape. Singapore's narrative has also been pigeonholed into the histories of ethnic "Chinese, Indians, Malays, and others" in the territory, mirroring the administrative classifications of the state.

As highlighted by Father Fortier, priest of a Malayalee Catholic Church outside the naval dockyard, most of the workers he knew had no conception of territorial boundaries and national identities. To them, Singapore was the naval base. ${ }^{18}$ According to Homi Babha, such imaginings support a revised understanding of the past:

Where once, the transmission of national traditions was the major theme, [...]. Perhaps now we can suggest that transnational histories of migrants, the colonised, or political refugees may be the terrain. [...]. The centre of such study would neither be the sovereignty of national cultures, nor the universalism of human culture, but a focus on those "freak social and cultural displacements" $[\ldots] .{ }^{19}$

Away from the meta-narrative of grand strategies and nation-building, the naval base was also an intersection of populations, societies, and cultures, and also a site of contestation between labour and empire. As noted by Chris Berry, the naval base was home to agents such as migrant labourers, whose trajectories "meet, intersect, overlay, fragment and produce hybrid forms within a certain geographic space". ${ }^{20}$ Thus, the study of the labour

I7. C.J.W-L. Wee, "Our Island Story: Economic Development and the National Narrative in Singapore", in ibid., pp. I42-146.

I8. National Archives of Singapore [hereafter NAS], oral interviews, Father Alfred Fortier, Aoooro3I/Reels I-2.

19. Homi K. Bhabha, The Location of Culture (London [etc.], 2004), p.17.

20. Makarand Paranjape, "Displaced Relations: Diasporas, Empires, Homelands", in Makarand Paranjape (ed.), In Diaspora: Theories, Histories, Texts (New Delhi, 2002), p. 3. 
legacy of the naval base in Singapore serves to open up greater scope for a more autonomous, plural, and expansive historiography.

\section{ESTABLISHING THE COLONIAL WORKING CLASS IN THE IMPREGNABLE FORTRESS}

Although facilities were available for the Royal Navy in Singapore, it was only after the threat of Japanese expansion emerged during the interwar years that there was a larger-scale commitment to a huge naval dockyard in Singapore, one capable of housing an entire modern fleet. The base would in turn represent not just Britain's strategic commitment to its dominions and colonies "east of Suez"; more importantly, it projected the myth of what Gordon described as the "most obvious and impressive" elements of power of the Pax Britannica. ${ }^{21}$ It was also a monumental infrastructural undertaking, with quays 30 to 40 feet deep at low water, and I,000-foot graving docks fully equipped with workshops, power stations, storehouses, hospitals, and living quarters. ${ }^{22}$

However, a cosmopolitan working-class community was not in the minds of the naval planners in the early stages of construction. And the virtues of political loyalty were of greater consideration than those of skill and industry. Such notions were initially based on stereotypical generalities of ethnicity. This issue was first raised in 1924 in a Royal Navy Staff College paper highlighting the problems in recruiting Asian sources of labour. The ethnic Malays and Indians were said to lack skills and be unreliable, while their Chinese counterparts were associated with labour unrest. ${ }^{23}$ The Chinese were also found to be superstitious and stubborn, and to be well organized by their leaders, who were considered "bullies in a school of small boys". ${ }^{24}$

Drawing on the experience of the prolonged seamen's strike in Hong Kong in 1922, it was also assumed that the Kuomintang government possessed the power to cause general strikes among all Chinese labourers in the major Asian port cities. ${ }^{25}$ The paper went on to recommend the recruitment of Maltese labourers, who were thought to be "exceptionally good colonialists and settlers as well as skilled fitters who could work successfully in motor repair shops through the day in spite of the hot tropical climate". ${ }^{26}$ Although the Admiralty acted as a government

21. Donald C. Gordon, The Moment of Power: Britain's Imperial Epoch (Englewood Cliffs, NJ, I970), p. 78.

22. Lennox A. Mills, British Rule in Eastern Asia (Oxford, I942), p. I9.

23. From Secretary of Admiralty to Admiral Roger Keys, "Supply of Labour to the Singapore Dockyard”, Public Record Office, London, [hereafter PRO] ADM 298/1097/65, I924.

24. Ibid.

25. Ibid.

26. Ibid. 
employer, in terms of its attitude to Asian labour it shared notions similar to those held by European private enterprises. Regarding the need for their operatives to respond to modern methods of industrial discipline and regimentation, European colonial employers perceived their indigenous counterparts to be lacking in either the natural physique or mental capacity to conform to such practices. Hence, as opined by Syed Hussein Alatas, essentialized notions of colonial labour were gradually developed. In the case of British Malaya these involved representations such as the indolent Malay, the industrious but rebellious Chinese, and the docile but simplistic Indians. ${ }^{27}$ In turn, such racial characteristics served to determine the types of labour regime or "law and order" described by Ann Stoler in her study of labour discipline on colonial plantations. ${ }^{28}$ The subservience of colonial labour was further reinforced by a combination of legal and institutional mechanisms. ${ }^{29}$ Although the idea was considered, it was found to be impractical and too expensive to import Maltese labour. So labourers from the region were employed to construct and maintain the base, and, with some reluctance, Chinese mechanics were also employed in the dockyard.

Attempts to regulate the ethnic composition of the naval base were repeated after a strike in 1963 , when it was felt that the

[...] high proportion of Indians, many of Keralan origin who are not citizens of Malaya and Singapore are troublemakers by nature and political background [...]. There is no good reason why the different races should not be more evenly balanced. This is now the intention though the process must be gradual if racial difficulties are to be avoided. ${ }^{\circ}$

There were even calls to control the workforce by reducing the proportion of Indian bachelors occupying staff quarters at the base, as they were deemed to be the most active supporters of strikes. ${ }^{3 \mathrm{I}}$

The community that sprang up within and around the naval base went far beyond the intentions of the naval planners. Accompanying the development of the majestic dockyard was the rapid growth of a more colourful and cosmopolitan labour force that built and maintained the

27. Syed Hussein Alatas, The Myth of the Lazy Native: A Study of the Image of the Malays, Filipinos and Javanese from the I6th to the 2oth Century and its Function in the Ideology of Colonial Capitalism (London, 1977). Most Europeans had ambivalent perceptions of the ethnic Chinese as the hyper-capitalist race, among which industry and greed dominated. In comparison, Indians were seen as a source of cheap and docile labour, amenable to discipline and management. See Charles Hirschman, "The Making of Race in Colonial Malaya: Political Economy and Racial Ideology", Sociological Forum, I (1986), pp. 330-36I, 347.

28. Ann Stoler, Capitalism and Confrontation in Sumatra's Plantation Belt, I870-1979 (New Haven, CT, 1985 ), pp. 6-9.

29. Ibid., p.9.

30. PRO, ADM I/28400, "Answers to Questions in Admiralty Letter", CE III/C.E.56868/63 of I 2 November 1963 .

3I. PRO, ADM I/28400, "Report on Strike in the HM Naval Base, Singapore", 20 March 1964. 
base. This was reflected by The Straits Times in the early years of the facility's construction:

Six months ago, the naval base site at Seletar was still much as it had been since the China tea clippers warped their way through the Johore Straits. [...]. It was a wilderness of swamp with no evidence of human occupation other than a native village. [...]. A small township is arising among the rubble on the high ground around the straits and buildings of all kinds, European quarters, coolie lines, stores and offices are being constructed over a large area in surprising numbers. To the left of the little jetty at Seletar, 50-feet concrete piles, railing sleepers and masses of construction materials are stacked along the foreshore right along the Red House, evidence of buildings and other activities. ${ }^{32}$

Outside the base, an informal economy grew to service the routine demands of the dockyard. Farmland expanded to provided poultry and vegetable products to the dockyard, while grocers, eateries, and laundry and tailor shops were dotted across town centres to cater to both the naval staff and their civilian employees. As the demographer, John Humphrey, observed, the development of the naval base in Sembawang resulted in the formation of the satellite villages of Kampong Tanjong, Irau, Sembawang Village, Chong Pang Village, and Kampong Sungei Simpang. ${ }^{33}$ Many women also found work as maids in the households of British naval officers, who sometimes brought their entire families with them. The occupations were further segregated along ethnic lines as each community formed its own niches, expertise, and networks. The maids serving the British households were mainly Cantonese amabs (a term for a more distinguished class of maids) for example, while many laundry-shop owners were of Hainanese origin. ${ }^{34}$

\section{“SYMBOL OF OUR COLLECTIVE SENTIMENTS”: THE MALAYALEES AT THE NAVAL BASE}

The most prominent group within the mosaic of communities at the naval base were the Malayalees, who were estimated to have constituted around 30 per cent of the population of the main villages - compared with an average of 6 per cent in Singapore as a whole. ${ }^{35}$ The information we have

32. The Straits Times, 5 January 1926.

33. John W. Humphrey, Geographic Analysis of Singapore's Population (Singapore, 1985), p. I 3. See also Brenda S.A. Yeoh and Lily Kong (eds), Portraits of Places: History, Community, and Identity in Singapore (Singapore, 1995).

34. There is no statistical information available on the exact number of those providing support services around the military bases. Admiralty officials estimated that about 9,500 locals were either directly employed privately by the European staff or indirectly catering to their domestic needs in the British military installations in Singapore; PRO, ADM I I6.6I95, C.E. I3020/53 of 24 February 1962, "Phasing of rundown".

35. This is based on an estimate of the size of the entire Indian population; in some of the 


\section{Table I. Ethnic Indian population in British Malaya}

\begin{tabular}{lcccc}
\hline Indian groups & 1921 & 1931 & 1947 & 1957 \\
\hline Tamil & 387,309 & 514,778 & 460,985 & 634,681 \\
Telugu & 39,986 & 32,536 & 24,093 & 27,670 \\
Malayalee & 17,190 & 34,898 & 44,339 & 72,971 \\
Others & $\mathrm{n} / \mathrm{a}$ & $\mathrm{n} / \mathrm{a}$ & 15,968 & $\mathrm{n} / \mathrm{a}$ \\
Total southern Indians & 444,485 & 582,212 & 545,385 & 735,322 \\
Total all Indians & 470,180 & 621,847 & 599,616 & 820,270 \\
\hline
\end{tabular}

Source: Malaya, Comprising the Federation of Malaya and the Colony of Singapore: A Report on the 1947 Census of Population (London, I949), p. 78. The report on the census admitted that there were inadequacies in establishing a more accurate report due to the ignorance of many of the enumerators, who arbitrary categorized the Indian population into the main classifications of Tamils, Telugus, and Malayalees. The figures for 1957 are taken from Kernial Singh Sandhu, Indians in Malaya (Cambridge, I969), p. 237.

on the establishment of this group of workers in Singapore is vague. Originally associated with Malabar traders, the Malayalee population became a prominent southern Indian group in the census of Singapore from the I920s. Their numbers registered a significant increase after the war, attributed probably to both population pressures and poor employment prospects in Kerala. ${ }^{36}$ Table I below shows the increase in the Malayalee population in British Malaya between the censuses of I92I, I93 I, I947, and 1957.

The Malayalee population rose significantly compared with the other ethnic Indian groups. In Singapore, it increased from 4,378 in I 93 I to 9,7 I 2 in 1947 , and to 21,783 according to the 1957 census. ${ }^{37}$ The proportion of Malayalees in the overall ethnic Indian population rose from I4.I per cent in 1947 to 17.6 per cent in $1957.3^{38}$ The mostly male Malayalees were not highly prominent as a group until the late I940s, when naval officials started to recruit more Indian workers to counter the presence of what they regarded as strike-prone Chinese. As a report in 1963 commented: "They are more suited than the Chinese and the Malays to certain types of

available records the Malayalees were lumped together with their South Asian counterparts. See Agnes Fung Li Ning, "Growth of Settlements in Rural Singapore" (Honours thesis, National University of Singapore, Department of Geography, 1975), p. I7.

36. According to the 196I Indian population census, the population density in Kerala was one of the highest in the country, skyrocketing from 176 people per square mile in 1836 to I, I 27 per square mile in 196r. The state also had the third highest rate of unemployment in India (behind Delhi and West Bengal). Kerala's workforce was only 33.3 I per cent of the total population, while the national average was 43.98 per cent. See Census of India, I96I, vol. I (Delhi, 1967), p. 78, pp. $735-736$.

37. Census of Malaya, I947, p. 79; Sandhu, Indians in Malaya, p. 237.

38. Report on the Census of Population, 1957 (Singapore, 1964), p. 70. 
work; and they were recruited in large numbers as an act of policy after the I946 strike which was Chinese inspired."39

By the late 1950s, the vicinity of the base was known as "Kochu Keralm", or "Little Kerala", with significant Malayalee concentrations within and outside the naval dockyard. Temples and churches in the area catered mostly to the mainly Hindu- or Catholic-affiliated Malayalee workers, and operated alongside other Keralan-based cultural and social organizations..$^{\circ}$ The Malayalee workers generally coexisted alongside other immigrant communities and regarded their own presence as being merely transient; nonetheless, they were keen not to lose their social and cultural links with Kerala. Hence, they struggled to distinguish and separate themselves from their Tamil counterparts in the Hindu temples by insisting on practicing the Onam rituals, which originated from Kerala. However, other Malayalee Hindus chose to worship their deities in the privacy of their homes rather than being associated with Tamil-dominated Hindu temples. ${ }^{4 \mathrm{I}}$

A similar trend was observed in the Malayalee-based Syrian and Roman Catholic churches as well as in the Malabar mosque, where services were conducted chiefly in Malayalam..$^{42}$ And even though they preached the ideals of religious universalism and oneness, the Sri Narayanan mission and the Gurukulam were uniquely Malayalee, as they were founded and attended by believers of the Ezhava caste from the region of Malayalam. Divisions within these Malayalee-based institutions reflected issues of culture and ethnicity more than doctrine. Menon noted that Syrian Christians regarded themselves as superior to Roman Catholics, as the latter were considered to have a more diluted sense of Malayaleeness than the former. ${ }^{43}$

Aside from the socio-religious and religious institutions, there were also cultural associations promoting both Malayalam literature and performing arts. These associations included a library, a charity and two arts

39. PRO, ADM I/28400, “Answers to Questions in Admiralty Letter", CE III/C.E.56868/63 of I 2 November 1963.

40. Suresh Menon identified two Hindu temples, two Christian churches, a Muslim mosque, and two syncretic religious missions frequented by the Malayalee community in the vicinity of the naval base. See Suresh Menon, "Role of Religious Institutions and Associations in a Malayalee Neighbourhood” (Honours thesis, National University of Singapore, 1975/76), pp. I6-24.

4I. The two main temples were the Bala Subramaniam Holy See Temple, located within the naval base, and the Shiva Krishna Temple, located along the Sembawang main road. From his interviews, Menon found that even though the Holy See Temple was closer to where the labourers lived, it was not often patronized by the Malayalee community, especially during the Onam festival. He also found that Malayalee Hindus had a greater tendency to conduct religious activities in their own homes than in the public sphere. Ibid., p. 20.

42. Ibid., p. 23.

43. Ibid. 
organizations within the naval base. Formed in 1953, the Kerala Library was not only a literary centre; it acted too as a clubhouse for community gatherings and theatre performances. It was also a platform for the Malayalam-based newspaper, the Malaysia Malayalee, which attempted to establish a presence and readership among the Malayalee workers at the naval base. Attempts were also made to promote Kerala's traditional Kathakali arts through organizations such as the Kerala Association, formed in 1960, and the Singapore Kathakali Yogum. ${ }^{44}$

In fact, despite its marginal position in the British colony and the subsequent republic, the status of Malayalee culture became acknowledged by the governing powers. This was reflected by the inclusion of images depicting Kathakali dance on postage stamps issued by the Singapore government. ${ }^{45}$ Perhaps the most concrete recognition of the Malayalee presence, however, was the observance of the Onam celebrations as a de facto public holiday on the naval base, since most Malayalee workers would not have turned up for work. ${ }^{46}$ According to Menon, as a result those within the naval base, including non-Indians, became aware of Onam and the Malayalee presence. ${ }^{47}$

The prominence of the Malayalee community was also visible in the main trade unions at the naval base, which were formed in the late i 930 s but not formally registered after World War II. Both the Naval Base Labour Union (NBLU), comprising blue-collar workers, and the Singapore Admiralty Local Staff Union (SALSU), mainly made up of junior clerical staff, had a substantial Malayalee involvement, which even extended to executive committees and the union leadership. It was these trade unions, particularly the NBLU, which spearheaded much of the collective action and resistance against dockyard labour policies, and also influenced the larger political development of the colony. As the dockyard officials observed:

In general, industrial trouble is most likely to be generated among Indians, particularly those who are bachelors, those originating from Kerala and those whose families are not in Singapore. The Chinese are unwilling to commit themselves to one side or the other. The Malays are independent and likely to join in industrial trouble only if genuinely aggrieved..$^{8}$

44. For more details, see ibid., ch. 3, pp. 27-37.

45. Ibid.

46. Although Onam could be regarded as part of the celebration of the start of the harvest season, its mythology involves a Dravidian epic that harks back to the end of the golden age of Kerala, when its ruler Mahabali was cast down to Patala, the underworld, by Vamana, the dwarf incarnation of Vishnu. The latter, conceding to the appeals of the Mahabali subjects, allowed the defeated monarch to return once a year, the time of the visit being fixed in the first Malayalam month (between August and September). Census of India, 196I, vol. 7: Kerala: Fairs and Festivals of Kerala (Delhi, 1966), p. 5.

47. Ibid., p. 24.

48. PRO, ADM I/28400, "Appendix F: Lessons learned from the Strike and General Observations”, 6 December 1963. 


\section{STRATEGIC OPPORTUNITIES FOR DEFIANCE AT THE NAVAL BASE}

In creating a migrant transnational labouring class, the presence of the naval dockyard in Singapore engendered overlapping modes of political and industrial relations. Unlike their European counterparts, these interactions were not merely those of a class-based employer-worker relationship; they were also shaped by the broader undercurrents of colonialism, imperialism and nationalism. In this respect, the resistance of the labouring class at the naval base was not just a reaction to conditions of pay and work. Rather, it represented responses to the fundamental inequalities and uncertainties inherent in the global labour policies of the Admiralty. These responses ranged from passive and routine acts of individual insubordination to outright industrial action, not only against their British employers but also against the brutal Japanese military and the authoritarian postcolonial PAP government. As Paul Gilroy has said about the relationship between mass movements and political cultures:

Institutional patterns shape mass movements by shaping the collectivity out of which protest can arise. Institutional life aggregates people or disperses them, moulds group identities and draws people into settings in which collective action can erupt. [...]. Institutional roles determine the strategic opportunities for defiance, for it is typically by rebelling against the rules and authorities that people protest. 49

We will examine two aspects of this resistance; namely, the defiance of individuals even in the face of the harshest Japanese militarism, and the more formal protests by organized labour against the Royal Navy and its counterpart, later, in the Singapore government.

\section{SUBVERTING JAPANESE MILITARISM}

Some of the most animated accounts of everyday resistance by the weak at the naval base were provided by those who had worked under the Japanese naval authorities during their brief occupation of the dockyard from I9421945..$^{\circ}$ Though short-lived, the Japanese military domination of southeast Asia generally disrupted not only local economies and societies; it also

49. Paul Gilroy, There Ain't No Black in the Union Jack (London [etc.], 2002), p. 24. 50. Aside from several oral history records from the National Archives of Singapore, there are no available official records on labour relations in the naval dockyard under the Japanese. Under such circumstances, one can rely only on the oral testimonies of several former dockyard personnel who worked for the Imperial Japanese Navy during this period. These scattered accounts might reflect only a minority and so might not represent the dominant view. Nevertheless, I believe that these graphic accounts provide a rare glimpse of workers during Japan's occupation of Singapore. 
created a new social awareness and intensified social fault lines. ${ }^{5 \mathrm{I}}$ According to Cheah, the Japanese administration resembled its British predecessor. ${ }^{52}$ However, because of the exigencies of war the involvement of the Japanese authorities in the local economy was visibly more heavyhanded, forcing labour into sectors vital for the Japanese war effort. ${ }^{33}$ As such, the Japanese were eager to restore the naval dockyard the British had scorched. Like its predecessor, the Japanese navy needed civilian manpower both to reconstruct the base and for the myriads of responsibilities involved in its maintenance.

Labour was available, since the population was suffering from high unemployment and food shortages. But these workers soon realized the brutality of the work regime demanded by the Japanese naval officers. In part, this regime reflected the Japanese policy of militarization towards the conquered civilian population, which was compelled to learn Japanese martial customs and rituals. ${ }^{54}$ Civilian workers were constantly subjected to close body searches at checkpoints by Japanese sentries and auxiliary guards. They were also required to perform the morning ritual of bowing to the Emperor, as well as doing exercises before commencing work. Workers also had to master the Japanese language and learn the military anthems that were often sung during parades. Severe physical punishments were meted out even for the most trivial transgressions, and civilian workers who failed to greet their Japanese officers would be harshly slapped or beaten. Those found thieving or leaking military information were either imprisoned or executed. Underlining the harsh discipline workers were subjected to, Heng Chiang Ky, who used to ferry stores through the Japanese base, recalled: "The very moment you passed the sentry post, you were not allowed to stand up on a lorry [...] they didn't want us to look around and see what was going on." 55

Sansui bin Haji Taman, an ethnic Malay who had worked in the base under the Japanese, recounted more widespread defiance on the part of workers. Despite strict security, many successfully stole and smuggled food by concealing it under trucks and other vehicles leaving the base. Heng too described how he used to smuggle rice bags out of the base:

When you reached the naval base, our friends would be there - the Japanese storekeepers. They used to come down to our place; we used to give them beer.

5. Yoji Akashi, “The Japanese Occupation of Malaya”, in Alfred McCoy (ed.), Southeast Asia under Japanese Occupation (New Haven, CT, 1985), p. 59.

52. Cheah Boon Kheng, "The Social Impact of the Japanese Occupation of Malaya (19421945)", in ibid., p. 82.

53. See Paul Kratoska, The Japanese Occupation of Malaya: A Social and Economic History (London, 1998).

54. Ibid., pp. $85-86$.

55. NAS, oral interviews, Heng Chiang Ky, A000 I 2/08-9. 
So they said, "Take whatever rice you want." Anybody who had been to the naval base would know that there were millions of bags there. We just scooped them into the bag, tied them up, put them onto a lorry, kept them underneath official ones. We managed to get quite a bit $[\ldots]$ over three years. ${ }^{56}$

Workers often subverted Japanese songs and anthems by deliberately distorting their lyrics and tunes by exaggerating the accents of their local languages. On some occasions, such exaggeration provoked laughter among the less stringent Japanese officers. ${ }^{57}$ The tables were turned by the final weeks of World War II, when the Japanese naval authorities not only ceased to enforce the harsh regime but actually treated the workers with unusual kindness. In the meantime, according to Sansui, Asian workers regarded as collaborators were dealt with. He remembered a scene in which a notoriously cruel Ceylonese prison warden at the naval base was brutally lynched by the workers, under the eyes of his helpless Japanese superiors. ${ }^{8}$

The routine and subtle acts of resistance displayed by workers during the Japanese occupation reflected a more nuanced labour relationship. Instead of being completely cowed into submission or being reliant on heroic resistance fighters, as portrayed in the national historiographies, workers at the naval base were able to subvert the more deferential relationship demanded by Japan's naval commanders.

\section{“WE USED TO STOP WORK AT 4.30 PM": INDUSTRIAL ACTION AT THE NAVAL BASE}

Compared with the brief administration of its Japanese naval counterpart, the Royal Navy was a more benign employer. Since the I930s, it had extended welfare provisions and remuneration for its employees and their dependants. The naval base was also one of the first colonial institutions in Singapore to establish a labour arbitration system. By the eve of the Japanese invasion of Malaya in I94 I, the Admiralty boasted that it was one of the finest employers in the colony, even claiming that it had the "best accommodation quarters in Malaya", and "contented and happy workers".59 In theory, this claim was generally accurate. Not only were Asian civilian workers provided with cheap accommodation and food, free transport, education, and medical facilities (for themselves and their families), their trade-union representatives were recognized too. In fact, calling itself a "good employer", in I 963 the Admiralty even rejected localgovernment pressure to sack pro-union workers at the base, even though

56. Ibid. See too NAS, oral interviews, Sansui bin Haji Taman, Aooor93/or -3.

57. Ibid.

58. Ibid.

59. The Straits Times, I 8 September 1940. 
these workers were alleged to be fermenting labour unrest in the dockyard. ${ }^{60}$ By then, the naval dockyard could claim that

[...] there is a low crime rate, good productivity in the yard and a sense of well being caused by a promising outlook for employment and plenty of work at hand. Quite a lot is being done to improve the lot of Asian residents, particularly in the provision of sports facilities etc. ${ }^{6 \mathrm{I}}$

In fact, one of the nostalgic recollections by former workers on the naval base after its commercialization was the relatively shorter official working day, which stopped at $4.30 \mathrm{pm}$.

Such privileges were not, however, able to calm the underlying discontents of the naval-base workers. Most of their grievances were rooted in the Admiralty's difficulty in setting a labour standard and remunerative system that was both consistent with local rates and uniform across its bases around the world. The problem was further exacerbated by the complications of an uncertain budget, one which was determined by London's geo-strategic considerations and financial health. In addition, being one of the major employers in the colony, the naval authorities found themselves playing a greater political role in Singapore than they originally intended. To make matters worse, the Royal Navy was also a major provider of accommodation on the base to workers and their families, hence making any retrenchment problematic. These complications were made more acute by the social and occupational diversity of these workers, who comprised close to I०० grades of professionals from a host of ethnic and cultural backgrounds.

The dockyard officials warned that "[c]hanges in Service policies, directed from London, could materially affect the situation, even if the annual possibility of having to restrict civilian labour on purely financial grounds were removed". ${ }^{62}$ The need for stability was often strongly lobbied by the local administrators, be they the colonial governors or the Singaporean government, who feared that any major retrenchment might jeopardize the local economy and ferment industrial unrest. This concern was underlined most urgently by the British High Commissioner to Singapore:

I recognised that there can be no question of abandoning, for the sake of Singapore, the system of annual estimates. I do urge, however, that this system, as well as the arrangements for service planning, both in London and Singapore,

60. PRO, ADM I/28400, "From Singapore to Commonwealth Relations Office", no. TOO, 7 October 1963 .

6r. PRO, ADM I/28400, "Report on Relations with the NBLU", $0256 / 33 / 59,23$ November 1959 .

62. Ibid. Extracts from Sir William Goode, United Kingdom Commissioner in Singapore, to Colonial Office, 3 September 1959. 
should be conducted, so far as this small but vital part of the world is concerned, with due regard to the political realities on which, ultimately, our whole position here depends. ${ }^{63}$

From the point of the workers, it meant dealing with the perceived unjust disparities between their wages and working conditions and those of other government sectors in Singapore and of their counterparts at other overseas bases. Any retrenchment and dismissals caused either by redundancies or individual factors meant not just job losses, but also the eviction of entire families from their quarters - and subsequently, for most foreign workers, from Singapore. And the need for dockyard officials to relay proposals to London made by labour representatives was seen as delaying tactics by the arrogant colonial masters.

A report sent by the Commodore Superintendent of the dockyard in Singapore to the Secretary of the Admiralty noted that:

Too little thought and effort have been devoted to man-management in the Dockyard for many years past; and at all levels. There are severe language barriers which make frank consultations between the Europeans and Asians difficult, but the alternative of rule by a benevolent dictatorship, acceptable a quarter of a century ago, is not acceptable today. ${ }^{64}$

From the early days of the naval base's construction, workers there did not readily accept the status quo, having conducted five major strikes between I930 and I968 (when the base closed). Even without labour organizations, in 1930 the construction workers at the base started to organize themselves against moves by one of the labour contractors to significantly slash their wages. This cut came at a time when workers were already earning less than minimum wages, with no compensation and minimal food allowances. ${ }^{65}$ The strike lasted about a week and was resolved after assurances by Royal Navy officials that wages would not be reduced. It also heralded broader labour reforms from a once reluctant Admiralty. From then on, it accepted the terms of the colony's labour ordinances, which bound it to provide hospital care and housing for its employees and their dependents. ${ }^{66}$

Another strike broke out in I946, even before normality had returned to the colony after the disruptive period of Japanese occupation. Although the dockyard had immediately embarked on a massive recruitment drive for the purpose of increasing postwar employment, it was unable to keep

63. Ibid.

64. PRO, ADM I/28400, "Answers to Questions in Admiralty", Letter CE III/CE 56868/63 of I 2 November 1963 .

65. The Straits Times, 20-2 I August 1930. Another minor strike at the naval base took place in September 1936 after 7 I coolies at the site downed tools for a few hours in support of a general strike by municipal sanitary workers. Ibid., i 7 September 1936.

66. PRO, $\mathrm{CO}_{273} / 568 \mathrm{D}$. I33/30, I3 November 1930. 
wages above hyperinflation rates or to ensure sufficient numbers of the Javanese labourers forced to work during the Japanese occupation were made redundant and repatriated for free. ${ }^{67}$ This culminated in an industrial stoppage lasting some three weeks, from 22 July to I 3 August 1946. It eventually fizzled out, with little achieved on either side. ${ }^{68}$

The labour scene in the naval dockyard became more prominent by the early 1950s, with the NBLU engaged in two industrial disputes, in 1952 and 1955. The chronic issue of cost-of-living allowances as well as other unfulfilled demands for paid sick leave and annual leave aggravated talks between the NBLU and the dockyard management. Angered by the refusal of the Royal Navy to accept their demands, the union openly "deplored the odium of discrimination against the Asian industrial employees $[\ldots]$ for there is no justification for granting European industrial employees of the Naval Base establishment rights while denying them to their Asian counterparts" ${ }^{69}$ The NBLU voted for strike action and the workers laid down their tools from 22 December 1952 to 7 January the following year, when work was resumed after both parties agreed to external arbitration.

The same issue was raised during the arbitration process by Lee Kuan Yew, then a young legal adviser to the union, who contended that:

As the [Armed] service departments and the government of Singapore were all alike organs of the government of the British Crown, it was logical and proper that they should speak with one united voice on this matter of wages, the corollary being that the dominant voice should be that of the local government. ${ }^{70}$

The arbitration body did not recognize the claims of the NBLU, however, even though it recommended that concessions be made to the union. Nonetheless, the entire episode was significant as it touched a raw nerve among the British administrators. To the Civil Lord, the claims of the NBLU were "in effect a challenge to our whole wage policy overseas", ${ }^{11}$ and "had also subjected the entire Admiralty to the prospects of being sucked into a financial bottomless pit worldwide with similar claims if it set a precedent by giving into NBLU's demands". ${ }^{72}$

The NBLU moved towards a more confrontational stage in the midi950s under the leadership of Sydney Woodhull, a university-educated

67. The Straits Times, 29 October 1946.

68. PRO, CO953/43/4/3, R.H. Oakley, Controller of Labour, Singapore, "Report on Labour Unrest in Singapore during the period I-Is October I946”, 29 October 1946.

69. PRO, ADM I/23524, ref. no. AS/I I/52, I May 1952.

70. PRO, ADM r/24666, "Award by Arbitrator in Reference between NBLU and the Lords Commission of the Admiralty", i I March i953, p. 3.

71. PRO, ADM r/23524, F.W. Moltenshead, U.S.E. (C), Io November 1952.

72. Ibid., Memorandum on the Present Labour Situation in HM Naval Base, Singapore, November 1952. 
Sinhalese who was made General Secretary in I954. Woodhull was responsible for organizing a sixteen-day strike among workers in 1956 over the eviction from the base's living quarters of a sacked worker and his family under the pretext of having to cater to the long waiting list for accommodation. ${ }^{73}$ Not only did the NBLU win for the man an extension of his right to stay, it also earned substantial benefits for its members. These included a pay increase of is per cent, backdated 6 months, amounting to a cost for the Admiralty of I.5 million dollars, in addition to a reduction in transport charges and working hours, a settlement that the media heralded as the year's biggest wage settlement in the colony. ${ }^{74}$

Though Woodhull was temporarily detained in 1956 accused of subversive activities, he inspired a more uncompromising and coherent sense of solidarity among the naval-base workers. Released in 1958, Woodhull was appointed adviser to the NBLU by the new postcolonial People's Action Party (PAP) government following its election victory in I959. The dockyard officials reported from Singapore that "from that time onwards, the union exerted a great deal of pressure on the dockyard management $[\ldots]$ and exists as a background irritant" ${ }^{75}$ It became more cautious in its dealings with the NBLU and the naval-base workers. In dealing with disciplinary cases, "great care was taken to exercise correct procedures in line with that of the U.K. dockyards", ${ }^{76}$ as the management was uncertain whether tough measures "would do more harm than good in the explosive situation in Singapore". ${ }^{77}$ Even in the face of a strike call in I96 I by about I 50 clerical workers at the base, the dockyard recommended that "it would undoubtedly be better if we can refrain from threats which are unlikely to be carried out" ${ }^{7}$

\section{NAVAL BASE BESIEGED: THE I 963 STRIKE}

Fortune turned against the NBLU by 1963 following the rearrest of Woodhull and his associates at the naval base by the Singapore government for allegedly having contacts with the outlawed Malayan Communist Party (MCP). Woodhull's successor was Michael Fernandez, a Malayalee possessing political leanings similar to those of Woodhull. Fernandez, however, faced a more complicated situation, having to deal with the

73. The Straits Times, 3 I January 1956 to 3 February 1956.

74. The Straits Times, I7 February 1956.

75. PRO, ADM I/28400, From the Commodore Superintendent to the C-in-C Far East Station,

"Report on Relations with the NBLU", 23 November 1959.

76. Ibid.

77. PRO, ADM I/28400, Civil Establishment Branch IV, CE 58334/6I, I9 December I96I.

78. Ibid. 
hostile state apparatus of the PAP government and a labour force more internally divided between his followers and pro-government workers.

Against odds greater than those during the previous decade, Fernandez was able to bring NBLU members out on a strike that was to last for more than a month. It was a period of highly charged emotions, and dramatic conflicts. The strike commenced at midnight on 7 October 1963, with attempts by the NBLU to station pickets within and around the naval base in the hope of dissuading blacklegs from going to work - in what the authorities described as imposing a "stage of siege" at the dockyard.79 The management at the base and the Singapore government regarded the strike as an illegal industrial action forced through by a well-organized minority of communist agitators bent on violence and disruption. To Fernandez and his supporters, however, it demonstrated the legitimacy of the NBLU's grievances and the solidarity of the workers, who were willing to risk their jobs in such an adversarial political climate.

Hence, while the state interpreted pickets lines outside the main gates of the naval base as unlawful intimidation of those attempting to go to work, the strikers saw it as peaceful persuasion. As a result, heated confrontations and skirmishes broke out between strikers and the naval and local police, as well as among different groups of workers. Clashes took place particularly at the start of the working day, when buses would be ferrying workers to the base. In one instance, the conflict extended to the village of Chong Pang near the base, where about 300 to 400 people were involved in clashes between strikers and those going to work at around dawn. ${ }^{80}$ One piece of oral testimony by a former Malay electrician relayed how he and his fellow villagers tried to rush through one of the gates that were barricaded by mostly Indian workers after the villagers felt that they could no longer financially survive the strike. ${ }^{8 \mathrm{I}}$

Nonetheless, the strike should also be remembered for the cohesion displayed by the workers. Apart from braving oncoming buses, police batons and retaliating blacklegs, the strikers also had to face a loss of income and the grim prospect of being dismissed. Some even lay down on the roads leading to the main gates of the dockyards in order to obstruct buses ferrying workers to the base. The strikers were financially supported not only by union funds but also by residents close to the base. ${ }^{82}$ Although the dockyard and the Singapore government insisted that the strike involved just a minority of workers, its reports showed that fewer than a

79. PRO, ADMr/28400, "Strike Report: Day to Day of Major Events", 6 December 1963.

80. The Straits Times, 28 October 1963.

8I. NAS, 000784 Access: Ahmad bin Ismail. Reels I-2.

82. See the interview with Michael Fernandez in Liew Kai Khiun, "Raised Voices and Dropped Tools: Labour Unrest at the Harbour and Naval Dockyard in Singapore, 1952-1972" (MA thesis, National University of Singapore, 2003), pp. 199-202. 
quarter of the base's average daily workforce of 8,638 actually showed up for work during the strike. ${ }^{83}$

Though the strike lasted longer than previous disputes, it eventually met a tragic end when the government belatedly declared it illegal and subsequently deregistered the NBLU. The union leadership was marginalized and replaced by a more compliant faction. In the case of those workers involved in the strike, the dockyard management cancelled bonuses for the next Deepavali (Hindu Festival of Lights). It proceeded to dismiss strikers, ranging from the NBLU leadership to ordinary workers. In all, about 200 workers were dismissed. ${ }^{84}$ The NBLU was later restored after a more compliant pro-government leadership was installed.

The thirty-three-day strike was the last major industrial action taken by the workers at the naval base, which had the most assertive and vibrant labour movement in British military facilities in the Far East. The crushing of the strike and the removal of its leaders spelt the beginning of the end of the strong and independent working-class community that had been in existence since the I930s. It also marked an end to a dramatic age in which the unions at the base were associated with such towering labour figures as Woodhull and Fernandez - men capable of organizing industrial protests. ${ }^{85}$ Aside from the emasculation of the labour movement, a grimmer prospect threatened several years later with news of the accelerated pullout of the British military presence from Singapore.

\section{NAVIES MELT AWAY: LABOUR AND THE BRITISH MILITARY WITHDRAWAL FROM SINGAPORE}

Far-called, our navies melt away;

On dune and headland sinks the fire:

Lo, all our pomp of yesterday

Is one with Nineveh and Tyre!

The above, taken from Kipling's Recessional, was quoted by the British Prime Minister Harold Wilson in a parliamentary debate; it was taken to signify the end of an "era" in the I960s. ${ }^{86}$ However, this passing of an era was considered an unpleasant eventuality for the postcolonial PAP government, since Singapore's economy and security were closely tied to Britain's military presence.

Despite being severely repressed in 1963 , the NBLU had not completely lost its vibrancy or relevance to the workers when trying to deal with the new situation. With a more cooperative leadership in place, the state

83. PRO, $\mathrm{ADM}$ i/28400, "Industrial Attendance during Strike", i i December 1963.

84. Ibid., p. I33.

85. Ibid., p. 136.

86. Lee, From Third World to First, p. 60. 
allowed the NBLU to rebuild its infrastructure (and, indeed, facilitated it) and paved the way for a merger with the SALSU, ${ }^{87}$ thereby creating a more effective working committee with the other service unions. Together with these other unions, the naval-base leaders even travelled to London to lobby the British government to recognize the republic's labour laws and improve its pension scheme to ensure its members were no worse off than their counterparts working for the Singapore government. ${ }^{88}$ Their efforts paid off when they won a wage agreement from the British government amounting to a total of $\$ 9$ million, a historic success achieved because the service unions were able to unite to form a combined team and negotiate jointly with the armed services. ${ }^{89}$

The agreement was superseded a year later by the announcement of the accelerated withdrawal of the British military, leaving the shocked service unions to scramble to negotiate terms relating to retrenchment and pension benefits for their workers, who also needed to be retrained for civilian work..$^{\circ}$ This was an easier task in the case of the naval base, which, with the facilities and skilled workers available, was converted to a government-linked commercial dockyard initially supervised by the British Swan Hunter group. The new company, Sembawang Corporation, re-employed and retained about 3,000 of the naval base's skilled workers. ${ }^{91}$ The naval base's remaining employees either retired, returned to India, or migrated to the United Kingdom.

However generous the final compensation package was for naval-base workers, it brought the whole legacy of the labouring community there to an end. The closure of the base effectively scuttled and scattered an entire generation of workers across different parts of the world. Though it gave

87. Moves to merge the two unions were initiated in 1966 in the presence of the labour minister Jek Yuen Tong, as part of efforts to negotiate with the British at a joint level; The Straits Times, I 3 May i 966.

88. Ibid., I7 May 1966. The delegation was formed after the 30,000-member Singapore Federation of Services Union organized a rally to protest against the British government's "meagre" pension scheme for the I,000 civilian staff due for retirement; ibid., 28 March I966. For a detailed breakdown of wage scales by individual grades and vocation see Newsletter of the National Trades Union Congress, I 2 January 1966.

89. Backdated to 1965 , the agreement provided wage increases to employees ranging from a minimum of $\$$ I 30 for an unskilled worker to a maximum of $\$$ I, 200 for the most senior technicalgrade employee. Daily rated workers were also to be converted to monthly rated staff. Ibid., I 3 January 1966.

90. These negotiations lasted until the eve of the formal pullout in I971, when fierce contentions emerged regarding the priority given to local workers over foreigners, as well as the frequency with which workers could draw their pensions. Meanwhile, the government and the unions took efforts to establish courses to retrain these workers for jobs in civilian industries. Most of the affected workers were from the Air Ministry and the army, and they had few commercial skills that could be used elsewhere.

91. See Melanie Chew, Of Hearts and Minds: The Story of Sembawang Shipyard (Singapore, I998). 
token recognition to its past, the new Sembawang commercial shipyard operated within a completely different framework from the Admiralty, as new regimes of corporate discipline set in, marking an end to a tradition in which the working day ended at $4.30 \mathrm{pm}$. As the Prime Minister, Lee Kuan Yew, warned the dockyard workers:

[The British Navy is] going to give [the base] to us together with I0,000 people and their families whom they have brought from Kerala, Madras, Malaya and Hong Kong into the base. They are presenting me with whole families together [...]. Over half have become Singapore citizens [...]. I am not going to come here next time, just to hear a long moan about more pay and better conditions of service. I am interested in productivity. ${ }^{92}$

The labour movement built up by the naval-base workers became a shadow of its past when the activists were either deported or detained and more draconian industrial-relations ordinances were passed. In the meantime, the physical, economic, and socio-cultural landscapes around the naval base were radically altered by the rapid expansion of new public housing estates into the area, occupied by residents with completely different world views about ethnicity and nationality, defined mainly by that of the state. In effect, the night-long dramas of the Kathakali theatres no longer resonated to street audiences from the districts known as the naval base.

\section{CONCLUSION: VERNACULAR CULTURES AND STUBBORN SOCIAL MOVEMENTS}

The minor, dissident traditions that have been constituted amid suffering and dispossession have been overlooked by the ignorant and the indifferent as well as the actively hostile. [...]. Nonetheless, vernacular cultures and the stubborn social movements that were built upon their strengths and tactics have contributed important moral and political resources to modern struggles in pursuit of freedom, democracy and justice. 93

On I November 1971, the Royal Navy bade farewell to Singapore, sailing out of the republic with a spectacular parade of warships under an umbrella of planes and helicopters. This spectacle marked the end of more than a century of British naval and colonial presence. ${ }^{94}$ he withdrawal of the British forces in Singapore heralded a new chapter in the republic's development, as it was forced to hasten the establishment of its own standing army and to industrialize its economy. This grand exit was also a

92. PRO, OD 39/79. Transcript of speech given by the Prime Minister, Lee Kuan Yew, at the Dockyard Workers' National Day celebration dinner, 2I March I967.

93. Paul Gilroy, Between Camps: Nations, Cultures and the Allure of Race (London [etc.], 2004), p. I 3.

94. The Straits Times, I November I97I. 
dignified end to the legacy of labour at the British bases, which, at their peak, employed almost 40,000 civilians and accounted for about 30 per cent of the island's gross domestic product.

Cast onto the sidelines of official histories and mainstream historiographies, the workers at the naval base fostered vibrant vernacular cultures and stubborn social movements in the course of fifty years. The organic growth of a diverse workforce at the naval base dashed the racialized ideals of naval planners about subservient and dependent colonial labourers. In the process, otherwise demographically marginalized ethnic groups such as the Malayalee community had a more prominent impact on the base. Despite being from largely impoverished backgrounds, the Malayalees carved out flourishing cultural and religious spaces through their Kathakali theatres groups, Malayalam libraries, and a variety of religious organizations within the naval dockyard.

In the realm of labour politics, the workers at the base also demonstrated resilient defiance against the hegemony of their employers and governments from the early stages of the construction of the base in the I920s to its final commercialization in the r960s. Neither the indifference of contractors involved in the construction of the base, nor the brutality of the Japanese military during the occupation, nor the purse strings of the Admiralty, nor the arbitrary measures of the postcolonial PAP government could cow the workers completely. From routine and subtle acts of non-compliance, to spontaneous walkouts and more organized industrial action by trade unions, the naval-base workers were able to stage challenges to the establishment they worked for. Occupying a vital strategic position, the activities of the naval-base workers also impacted on the larger political direction of Singapore, particularly during the I950s and ig6os.

Ironically, even though the labour movement centred on the naval base could be regarded as a locus of resistance to British hegemony, its fortunes were inevitably tied to those of the Empire. The ebbing away of London's geopolitical reach also coincided with the gradual dissipation of the fabric of the base's working-class culture and the eventual dispersion of the workers themselves. The physical landscape of the former HM Dockyard in Singapore has changed beyond recognition in the decades since the British withdrawal. But the legacy of those workers who passed through the Canberra Gates every day under four national flags (Britain, Japan, Malaysia, and Singapore) carried a discourse beyond that of empire and nation-state. 